Jie Wang, Hongyu Guan*, Chunhua Ge, Ping Fan*, Xijuan Xing and Yunshan Shang

\title{
Azocalix[4]arene with three distal ethyl ester residues as a highly selective chromogenic sensor for $\mathrm{Ca}^{2+}$ ions
}

https://doi.org/10.1515/hc-2017-0239

Received December 6, 2017; accepted January 26, 2018; previously published online April 27, 2018

\begin{abstract}
Three azocalix[4]arenes with distal ethyl ester residues, 5-phenylazo-25,26,27-tris[(ethoxycarbonyl) methoxy]-28-hydroxycalix[4]arene (2), 5-(o-methylphenyl) azo-25,26,27-tris[(ethoxycarbonyl)methoxy]-28-hydroxycalix[4]arene (3), 5-(p-Methylphenyl)azo-25,26,27-tris[(ethoxycarbonyl)methoxy]-28-hydroxycalix[4]arene (4), were synthesized and their binding properties with metal ions were investigated by ultraviolet (UV)/visible spectroscopy. The chromogenic behavior of these compounds upon metal ion complexation indicates a specific selectivity toward $\mathrm{Ca}^{2+}$ ion in the presence of other cations tested. The stoichiometry of 3 to $\mathrm{Ca}^{2+}$ ion in the complex is 1:1 and the stability constant of the complex is $1.28 \times 10^{4} \mathrm{M}^{-1}$.
\end{abstract}

Keywords: azocalix[4]arene; calcium ion; chromogenic sensor; ion recognition.

\section{Introduction}

Over the past two decades, significant efforts have been focused on the design and synthesis of chemosensors that are able to selectively recognize target molecules or ions, particularly those with color or fluorescent response functions [1-6]. Converting this recognition into an optical signal, a reaction process or a chemical species that could be observed and detected by the naked eye or with inexpensive equipment, is of interest [7-9]. Azocalixarenes have been reported to change color upon complexation with specific metal ions [10-13]. In many cases, the azo moiety is introduced into calixarenes at the upper rim to facilitate the monitoring of the binding process upon complexation.

*Corresponding authors: Hongyu Guan and Ping Fan, College of Chemistry, Liaoning University, Shenyang 110036, People's Republic of China, e-mail: guanhongyu@lnu.edu.cn (H. Guan);

pingfan@Inu.edu.cn (P. Fan)

Jie Wang, Chunhua Ge, Xijuan Xing and Yunshan Shang: College of Chemistry, Liaoning University, Shenyang 110036, People's Republic of China
Many studies on azocalixarene derivatives also involve the functionalization of the lower rim with metal-chelating groups, such as carboxylic acid, ester and other groups [14-18]. Other studies focus on azocalix[4]arenes functionalized with distal esters as chromogenic receptors [19-24].

An antracenylazo derivative was synthesized [19] and shown to undergo complexation with $\mathrm{Eu}^{3+}, \mathrm{Ag}^{+}$and $\mathrm{Cu}^{2+}$ ions [20]. Subsequently, it was reported that this calixarene forms complexes with $\mathrm{Ca}^{2+}, \mathrm{Pb}^{2+}, \mathrm{Sr}^{2+}$ and $\mathrm{Ba}^{2+}$ ions as well, with a moderate selectivity toward $\mathrm{Ca}^{2+}$ ions [21]. On the other hand, it was reported that an azocalix[4]arene with four distal ester groups undergoes complexation with $\mathrm{Ag}^{+}$, $\mathrm{Hg}^{+}$and $\mathrm{Hg}^{2+}$ cations [22]. Similar azocalixarene species bearing diester groups on the lower rim were used for the selective extraction of $\mathrm{Pd}^{2+}$ ion in the presence of some other cations in hydrochloric acid solution [23]. Using the azocalixarenes as extractants made the extraction process visible. Additional applications have been reported [24].

\section{Results and discussion}

In an effort to synthesize azocalixarene species that exhibit unique chromogenic responses to specific metal ions, three new azocalix[4]arenes with distal ethyl ester groups on the lower rim, 5-phenylazo-25,26,27-tris[(ethoxycarbonyl) methoxy]-28-hydroxycalix[4]arene (2), 5-(o-methylphenyl) azo-25,26,27-tris[(ethoxycarbonyl)methoxy]-28-hydroxycalix[4]arene (3), 5-(p-methylphenyl)azo-25,26,27-tris[(ethoxycarbonyl)methoxy]-28-hydroxycalix[4]arene (4),

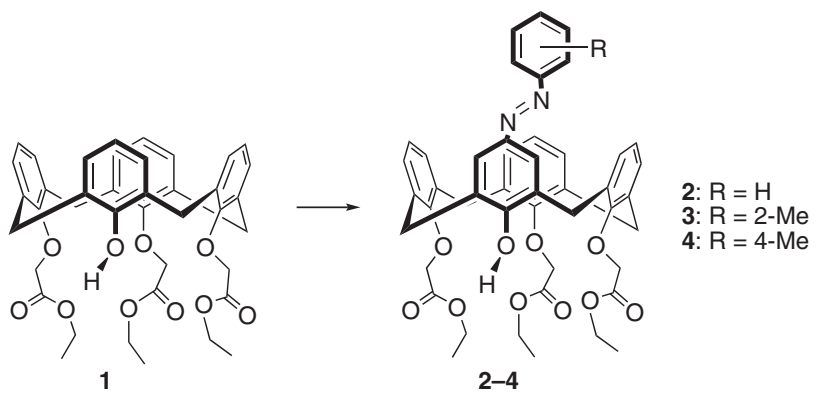

Scheme 1 Synthesis of calix[4]arenes 2-4. Reagents and conditions: $\mathrm{NaNO}_{2} / 4 \mathrm{~N} \mathrm{HCl}$, pyridine, $0^{\circ} \mathrm{C}, 5 \mathrm{~h}$, aniline in acetone for 2 , $o$-toluidine in acetone for $\mathbf{3}, p$-toluidine in acetone for 4 . 

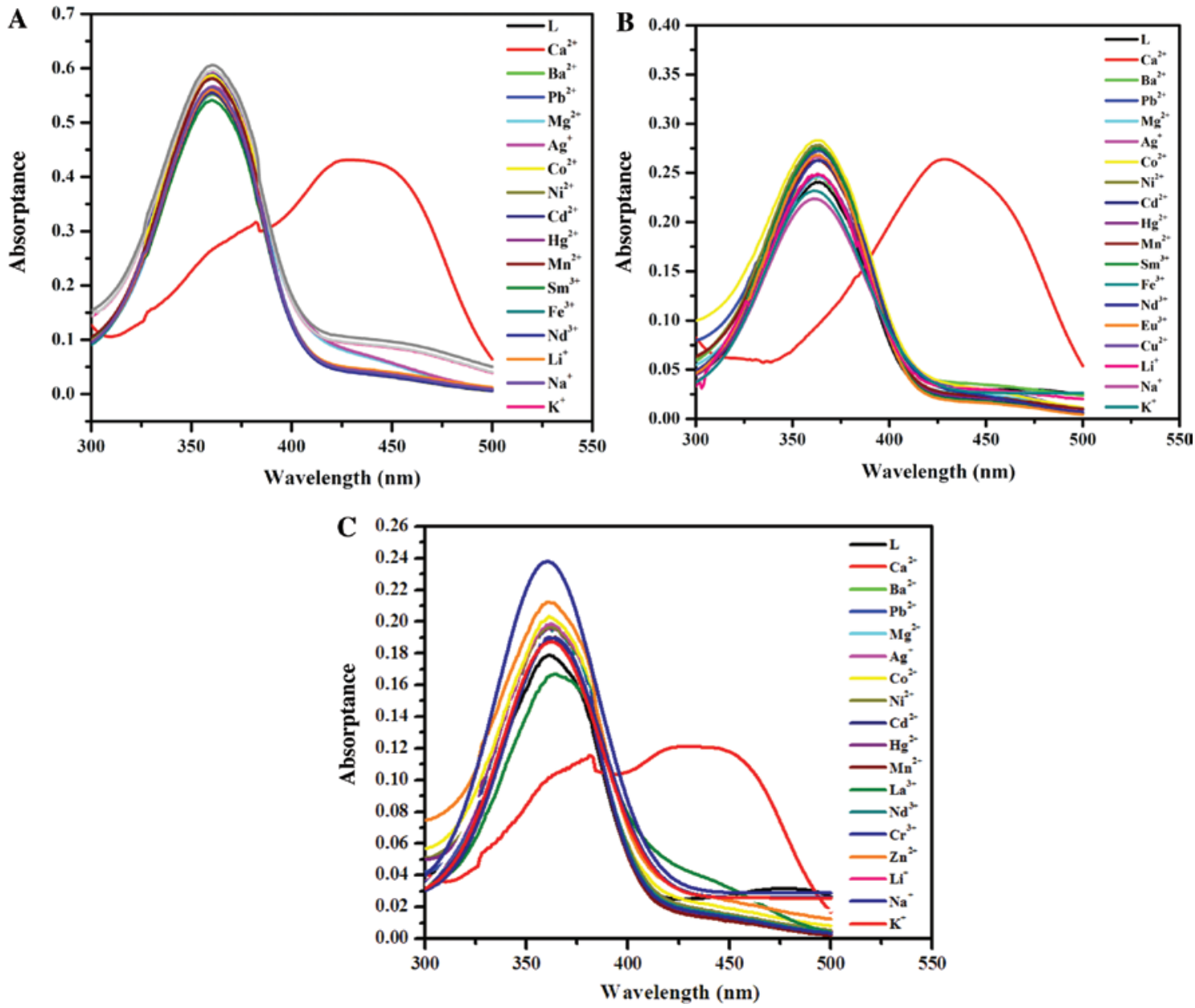

Figure 1 Absorption spectra of $2(A), 3(B)$ and 4 (C) in the absence and the presence of various metal ions in acetonitrile.

were synthesized using methods inspired by Shinkai et al. [25] and Tóth et al. [26]. The synthesis of compounds 2-4 is illustrated in Scheme 1.

In acetonitrile, compounds $\mathbf{2 - 4}$ show a strong ultraviolet/visible (UV/Vis) absorption peak near $362 \mathrm{~nm}$ (Figure 1), which can be attributed to the $\pi-\pi *$ transition of the $-\mathrm{N}=\mathrm{N}$ - bond [21]. The binding properties of the three compounds with metal ions were investigated by monitoring UV/Vis spectral changes upon the addition of $\mathrm{Na}^{+}, \mathrm{K}^{+}$, $\mathrm{Li}^{+}, \mathrm{Mg}^{2+}, \mathrm{Ca}^{2+}, \mathrm{Ba}^{2+}, \mathrm{Fe}^{3+}, \mathrm{Co}^{2+}, \mathrm{Ni}^{2+}, \mathrm{Zn}^{2+}, \mathrm{Cd}^{2+}, \mathrm{Hg}^{2+}, \mathrm{Pb}^{2+}$, $\mathrm{Mn}^{2+}, \mathrm{Ag}^{+}, \mathrm{La}^{3+}, \mathrm{Nd}^{3+}, \mathrm{Eu}^{3+}, \mathrm{Sm}^{3+}$ and $\mathrm{Cr}^{3+}$ ions. With the exception of $\mathrm{Ca}^{2+}$, addition of these ions does not significantly alter the absorption peaks of compounds 2-4. Upon addition of $\mathrm{Ca}^{2+}$ to 2 , the intensity of absorption band at $362 \mathrm{~nm}$ decreases and a new band appears at $429 \mathrm{~nm}$. The UV/Vis spectral changes for compounds $\mathbf{3}$ and $\mathbf{4}$ are similar to those observed for compound 2 (Figure 1 ).

These results indicate that compounds $2-4$ possess a specific selectivity for $\mathrm{Ca}^{2+}$ ion. Compounds 2-4 may

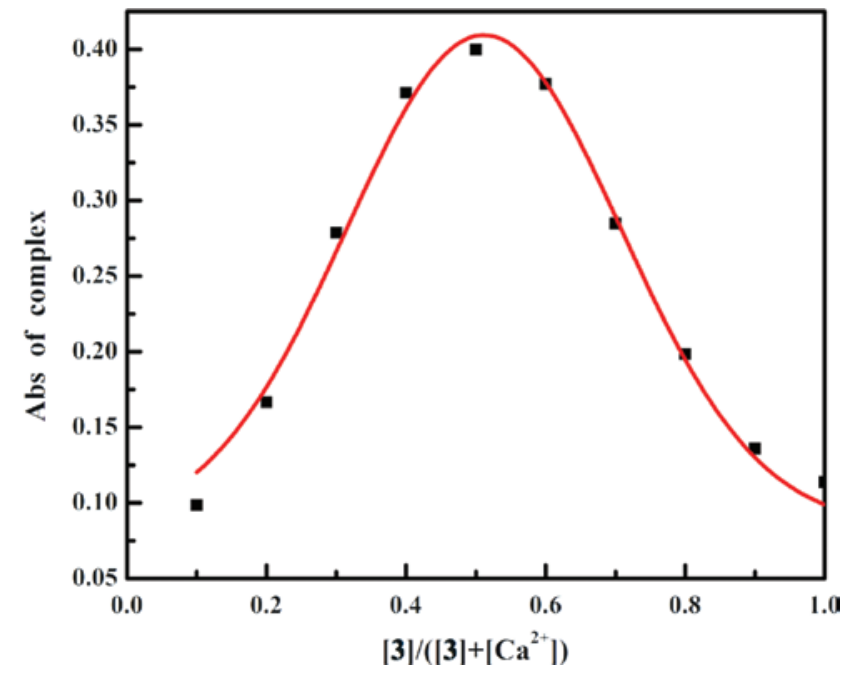

Figure 2 Job's continuous variation plot for $3-\mathrm{Ca}^{2+}$ at $429 \mathrm{~nm}$. $\left([3]+\left[\mathrm{Ca}^{2+}\right]=1 \times 10^{-3}\right)$. 


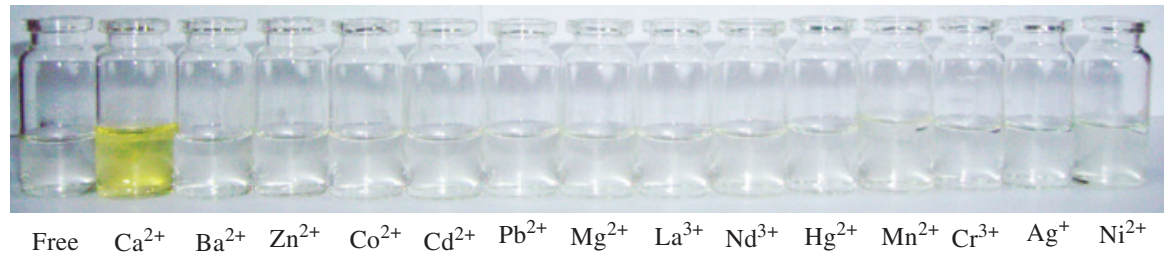

Figure 3 Color of the solution of compound $4\left(1.0 \times 10^{-5} \mathrm{M}\right)$ in the presence of various metal cations $\left(4.0 \times 10^{-5} \mathrm{M}\right)$.

exist in two tautomeric forms containing azophenol and quinone-hydrazone moieties [12, 13, 27]. The metal complexation may induce a release of proton from the azophenol to the quinone-hydrazone function. When compounds 2-4 undergo complexation with $\mathrm{Ca}^{2+}$ ion, the formation of quinone-hydrazone tautomer results in the weakening of the double bond character of the azo moiety. As a result, the UV/Vis spectrum is altered, with the new band appearing at $429 \mathrm{~nm}$.

The complexation ratio between azocalixarene 3 and $\mathrm{Ca}^{2+}$ was determined using a Job's plot (Figure 2). The experiment was conducted using a $429 \mathrm{~nm}$ wavelength. As can be seen, the maximum point is at a molar fraction of [azocalixarene 3]/([azocalixarene 3] $+\left[\mathrm{Ca}^{2+}\right]$ ) of approximately 0.5 , indicating a host-metal ion complex ratio of 1:1. The association constant for the $3-\mathrm{Ca}^{2+}$ complex in acetonitrile is $1.28 \times 10^{4} \mathrm{M}^{-1}$ as determined by a BenesiHilderbrand plot [12, 28].

A color change is observed upon mixing the ligand 2, 3 or $\mathbf{4}$ and $\mathrm{Ca}^{2+}$ cation. For example, when a dilute colorless solution of compound 4 is treated with $\mathrm{Ca}^{2+}$ (Figure 3 ), the solution becomes yellow. No color change is observed in the presence of other metal cations.

\section{Conclusions}

Azocalix[4]arenes 2-4 exhibit a remarkable selectivity toward complexation of $\mathrm{Ca}^{2+}$ ion, and the interaction is associated with a color change, suggesting possible applications as new chromogenic sensors for $\mathrm{Ca}^{2+}$ ion-sensing materials. The hydroxyl and distal ethyl ester units of azocalixarenes 2-4 take part in binding with $\mathrm{Ca}^{2+}$ ion, and the azo moiety is necessary for the color recognition of $\mathrm{Ca}^{2+}$ ion.

\section{Experimental}

\section{Synthesis of compounds 2-4}

An ice-cold solution of $\mathrm{NaNO}_{2}(0.90 \mathrm{~g})$ in hydrochloric acid (4 M, $6 \mathrm{~mL}$ ) was added to a solution of aniline, $o$-toluidine or $p$-toluidine
(0.86 mmol) in acetone $(5 \mathrm{~mL})$. The mixture was stirred for $20 \mathrm{~min}$ and then added to an ice-cold solution of calix[4]arene $1(0.13 \mathrm{~g}$, $0.19 \mathrm{mmol})$ in pyridine $(8 \mathrm{~mL})$ [25]. The colored mixture was stirred for $5 \mathrm{~h}$ at $0^{\circ} \mathrm{C}$ and then treated with hydrochloric acid $(4 \mathrm{M}, 50 \mathrm{~mL})$. The resultant colored precipitate was subjected to chromatography on silica gel eluting with ethyl acetate/petroleum ether (1:5).

5-Phenylazo-25,26,27-tris [(ethoxycarbonyl)methoxy]-28hydroxycalix[4]arene (2) Yield 20\%; mp 199-201 ${ }^{\circ} \mathrm{C}$; IR (KBr): 3392, 2927, $1765 \mathrm{~cm}^{-1}$; ${ }^{1} \mathrm{H}$ NMR (300 MHz, DMSO- $d_{6}$ ): $\delta 1.26(\mathrm{t}, J=7 \mathrm{~Hz}$, $\left.3 \mathrm{H}, \mathrm{OCH}_{2} \mathrm{CH}_{3}\right), 1.34\left(\mathrm{t}, J=7 \mathrm{~Hz}, 6 \mathrm{H}, \mathrm{OCH}_{2} \mathrm{CH}_{3}\right), 3.32(\mathrm{~d}, J=13 \mathrm{~Hz}$, $2 \mathrm{H}, \mathrm{ArCH}_{2} \mathrm{Ar}$ ), 3.47 (d, $J=13 \mathrm{~Hz}, 2 \mathrm{H}, \mathrm{ArCH}_{2} \mathrm{Ar}$ ), 4.14 (q, $J=7 \mathrm{~Hz}, 2 \mathrm{H}$, $\left.\mathrm{OCH}_{2} \mathrm{CH}_{3}\right), 4.29\left(\mathrm{q}, J=7 \mathrm{~Hz}, 4 \mathrm{H}, \mathrm{OCH}_{2} \mathrm{CH}_{3}\right), 4.41(\mathrm{~d}, J=13 \mathrm{~Hz}$, $\left.2 \mathrm{H}, \mathrm{OCH}_{2} \mathrm{CH}_{3}\right), 4.51\left(\mathrm{~d}, J=15 \mathrm{~Hz}, 2 \mathrm{H}, \mathrm{OCH}_{2} \mathrm{COO}\right), 4.66$ (d, $J=15 \mathrm{~Hz}, 2 \mathrm{H}$, $\mathrm{OCH}_{2} \mathrm{COO}$ ), 4.97 (d, J=13 Hz, 2H, OCH $\mathrm{COO}_{2}$ ), 5.13 (s, 2H, OCH $\mathrm{COO}$ ), $6.56(\mathrm{~m}, 6 \mathrm{H} \mathrm{Ar}), 6.93(\mathrm{t}, J=7 \mathrm{~Hz}, 1 \mathrm{H}, \mathrm{Ar}), 7.13$ (d, $J=7 \mathrm{~Hz}, 2 \mathrm{H}, \mathrm{Ar}), 7.18$ (s, $1 \mathrm{H}), 7.46$ (m, 3H, Ar), 7.74 (s, 2H, Ar), 7.88 (d, $J=8 \mathrm{~Hz}, 2 \mathrm{H}, \mathrm{Ar}) ;{ }^{13} \mathrm{C}$ NMR (75 MHz, DMSO- $d_{6}$ ): $\delta 171.0$ (CO), 169.2 (CO), 156.9, 155.9, 153.7, 153.0, 145.3, 135.8, 133.2, 132.0, 129.9, 129.5, 129.3, 129.0, 128.7, 128.4, 124.2, 123.8, 123.4, 122.3, $72.1\left(\mathrm{OCH}_{2} \mathrm{CO}\right), 70.3\left(\mathrm{OCH}_{2} \mathrm{CO}\right), 61.1\left(\mathrm{~s}, \mathrm{OCH}_{2}\right), 60.3$ $\left(\mathrm{OCH}_{2}\right), 31.8\left(\mathrm{CH}_{2}\right), 31.0\left(\mathrm{CH}_{2}\right), 14.2\left(\mathrm{CH}_{3}\right)$. HR-MS. Calcd for $\mathrm{M}^{+}: m / z$ 702.7054. Found: $m / z 702.7060$.

5-(o-Methylphenyl)azo-25,26,27-tris [(ethoxycarbonyl) methoxy]-28-hydroxy- calix[4]arene (3) Yield 30\%; mp 192$194^{\circ} \mathrm{C}$; IR (KBr): $3422,2927,1763 \mathrm{~cm}^{-1}$; ${ }^{1} \mathrm{H}$ NMR (300 MHz, DMSO- $d_{6}$ ): $\delta 1.27\left(\mathrm{t}, J=7 \mathrm{~Hz}, 3 \mathrm{H}, \mathrm{OCH}_{2} \mathrm{CH}_{3}\right), 1.34\left(\mathrm{t}, J=7 \mathrm{~Hz}, 6 \mathrm{H}, \mathrm{OCH}_{2} \mathrm{CH}_{3}\right), 2.72$ (s, $3 \mathrm{H}, \mathrm{ArCH}_{3}$ ), 3.32 (d, J=13.5 Hz, 2H, $\mathrm{ArCH}_{2} \mathrm{Ar}$ ), 3.47 (d, $J=13.5 \mathrm{~Hz}$, $2 \mathrm{H}, \mathrm{ArCH}_{2} \mathrm{Ar}$ ), 4.14 (q, $J=7 \mathrm{~Hz}, 2 \mathrm{H}, \mathrm{OCH}_{2} \mathrm{CH}_{3}$ ), 4.29 (q, $J=7 \mathrm{~Hz}, 4 \mathrm{H}$, $\mathrm{OCH}_{2} \mathrm{CH}_{3}$ ), 4.42 (d, $\left.2 \mathrm{H}, \mathrm{ArCH}_{2} \mathrm{Ar}\right), 4.51$ (d, $J=16 \mathrm{~Hz}, 2 \mathrm{H}, \mathrm{OCH}_{2} \mathrm{COO}$ ), 4.66 (d, $\left.J=16 \mathrm{~Hz}, 2 \mathrm{H}, \mathrm{OCH}_{2} \mathrm{COO}\right), 4.97$ (d, $J=13.5 \mathrm{~Hz}, 2 \mathrm{H}, \mathrm{ArCH}_{2} \mathrm{Ar}$ ), $5.13\left(\mathrm{~s}, 2 \mathrm{H}, \mathrm{OCH}_{2} \mathrm{COO}\right), 6.49-6.65(\mathrm{~m}, 6 \mathrm{H}, \mathrm{Ar}), 6.93(\mathrm{t}, J=7 \mathrm{~Hz}, 1 \mathrm{H}$, Ar), 7.12 (d, $J=7 \mathrm{~Hz}, 3 \mathrm{H}, \mathrm{Ar}), 7.28$ (m, 3H, Ar), 7.58 (d, $J=7 \mathrm{~Hz}, 1 \mathrm{H}$, Ar), 7.73 (s, 2H, Ar); ${ }^{13} \mathrm{C}$ NMR (75 MHz, DMSO- $\left.d_{6}\right): \delta 170.9$ (CO), 169.1 (CO), 156.6, 155.7, 153.8, 151.1, 145.7, 137.0, 135.8, 133.2, 132.0, 131.0, 129.4, 129.3, 128.6, 128.3, 126.3, 124.1, 123.8, 123.3, 115.4, 72.2 $\left(\mathrm{OCH}_{2} \mathrm{CO}\right), 70.2\left(\mathrm{OCH}_{2} \mathrm{CO}\right), 61.0\left(\mathrm{OCH}_{2}\right), 60.2\left(\mathrm{OCH}_{2}\right), 31.7\left(\mathrm{CH}_{2}\right), 31.0$ $\left(\mathrm{CH}_{2}\right), 17.5\left(\mathrm{CH}_{3}\right), 14.1\left(\mathrm{CH}_{3}\right)$. HR-MS. Calcd for $\mathrm{M}^{+}: \mathrm{m} / z 716.7320$. Found: $m / z 716.7311$.

5-(p-Methylphenyl)azo-25,26,27-tris[(ethoxycarbonyl)methoxy]28-hydroxycalix[4]arene (4) Yield 25\%; mp 151-153 ${ }^{\circ} \mathrm{C}$; IR (KBr): 3410, 2978, $1733 \mathrm{~cm}^{-1}$; ${ }^{1} \mathrm{H}$ NMR (300 MHz, DMSO- $\left.d_{6}\right): \delta 1.26(\mathrm{t}, J=7 \mathrm{~Hz}$, $3 \mathrm{H}, \mathrm{OCH}_{2} \mathrm{CH}_{3}$ ), 1.34 (t, $J=7 \mathrm{~Hz}, 6 \mathrm{H}, \mathrm{OCH}_{2} \mathrm{CH}_{3}$ ), 2.42 (s, 3H, $\mathrm{ArCH}_{3}$ ), 3.31 (d, $\left.J=13.5 \mathrm{~Hz}, 2 \mathrm{H}, \mathrm{ArCH}_{2} \mathrm{Ar}\right), 3.46$ (d, $J=13.5 \mathrm{~Hz}, 2 \mathrm{H}, \mathrm{ArCH}_{2} \mathrm{Ar}$ ), 4.14 (q, $J=7 \mathrm{~Hz}, 2 \mathrm{H}, \mathrm{OCH}_{2} \mathrm{CH}_{3}$ ), 4.29 (q, $J=7 \mathrm{~Hz}, 4 \mathrm{H}, \mathrm{OCH}_{2} \mathrm{CH}_{3}$ ), 4.40 (d, $J=13.5 \mathrm{~Hz}, 2 \mathrm{H}, \mathrm{ArCH}_{2} \mathrm{Ar}$ ), 4.50 (d, $J=15 \mathrm{~Hz}, 2 \mathrm{H}, \mathrm{OCH}_{2} \mathrm{COO}$ ), 4.65 (d, $J=15 \mathrm{~Hz}, 2 \mathrm{H}, \mathrm{OCH}_{2} \mathrm{COO}$ ), 4.96 (d, J=13.5 Hz, 2H, ArCH $2 \mathrm{Ar}$ ), 5.13 (s, $2 \mathrm{H}, \mathrm{OCH}_{2} \mathrm{COO}$ ), 6.47-6.63 (m, 6H, Ar-H), 6.93 (t, $J=7 \mathrm{~Hz}, 1 \mathrm{H}, \mathrm{Ar}-\mathrm{H}$ ), 
7.03-7.14 (m, 3H, Ar), 7.29 (d, J=8 Hz, 2H, Ar-H), 7.72 (s, 2H, Ar), 7.78 (d, $J=7.5 \mathrm{~Hz}, 2 \mathrm{H}, \mathrm{Ar}$ ); ${ }^{13} \mathrm{C}$ NMR (75 MHz, DMSO- $d_{6}$ ): $\delta 170.9$ (s, CO), 169.0 (s, CO), 156.5 (s), 155.6 (s), 153.6 (s), 151.0 (s), 145.2, 140.2, 135.7, 133.1, 131.9, 129.6, 129.4, 129.2, 128.6, 128.3, 124.1, 123.6, 122.2, 70.9 $\left(\mathrm{OCH}_{2} \mathrm{CO}\right), 70.2\left(\mathrm{OCH}_{2} \mathrm{CO}\right), 61.0\left(\mathrm{OCH}_{2}\right), 60.1\left(\mathrm{OCH}_{2}\right), 31.6\left(\mathrm{CH}_{2}\right), 30.9$ $\left(\mathrm{CH}_{2}\right), 21.3\left(\mathrm{CH}_{3}\right), 14.1\left(\mathrm{CH}_{3}\right)$. HR-MS. Calcd for $\mathrm{M}^{+}: \mathrm{m} / z$ 716.7320. Found: $\mathrm{m} / z 716.7383$.

Acknowledgments: This work was supported by the National Natural Science Foundation of China (grant 21171081), the Science Foundation of Education Department of Liaoning Province (grant L2011007) and the Foundation of Project 211 for Innovative Talents Training, Liaoning University. The authors also thank the colleagues and students who participated in this work.

\section{References}

[1] Liu, M. P.; Liu, T.; Li, Y.; Xu, H.; Zheng, B. Z.; Wang, D. M.; Du, J.; Xiao, D. A FRET chemsensor based on graphene quantum dots for detecting and intracellular imaging of $\mathrm{Hg}^{2+}$. Talanta 2015 , 143, 442-449.

[2] Liu, X. U.; Zhao, R. R.; Wei, Y. L. A rhodamine derivative for $\mathrm{Hg}^{2+}$ selective colorimetric and fluorescent sensing and its application to in vivo imaging. Chin. Chem. Lett. 2016, 27, 813-816.

[3] Xu, J.; Sun, Y. H.; Zhang, H. Rhodamine-based fluorescent chemosensor for $\mathrm{Hg}$ (II) with high selectivity in solution. Chinese J. Inorg. Chem. 2010, 26, 2189-2194.

[4] Baldini, L.; Casnati, A.; Sansone, F.; Ungaro, R. Calixarenebased multivalent ligands. Chem. Soc. Rev. 2007, 36, 254-266.

[5] Kim, J. S.; Quang, D. T. Calixarene-derived fluorescent probes. Chem. Rev. 2007, 107, 3780-3799.

[6] Kotzen, N.; Vigalok, A. The inside of metal calixarene chemistry. Supramol. Chem. 2008, 20, 129-139.

[7] Tan, L. V.; Lee, N. T. N. Spectrophotometric determination of lead in environmental samples by benzoic acid azophenylcalix[4]arene (BAPC). Internat. J. Chem. 2010, 2, 86-90.

[8] Menon, S. K.; Modi, N. R.; Patel, B.; Patel, M. B. Azo calix[4] arene based neodymium (III)-selective PVC membrane sensor. Talanta 2011, 83, 1329-1334.

[9] Bingol, H.; Kocabas, E.; Zor, E.; Coskun, A. Spectrophotometric and electrochemical behavior of a novel azocalix[4]arene derivative as a highly selective chromogenic chemosensor for $\mathrm{Cr}^{+3}$. Electrochim. Acta 2011, 56, 2057-2061.

[10] Bingol, H.; Kocabas, E.; Zor, E.; Coskun, A. A novel benzothiazole based azocalix[4]arene as a highly selective chromogenic chemosensor for $\mathrm{Hg}^{2+}$ ion: a rapid test application in aqueous environment. Talanta 2010, 82, 1538-1542.

[11] Chang, K. C.; Su, I. H.; Lee, G. H.; Chung, W. S. Triazole-and azo-coupled calix[4]arene as a highly sensitive chromogenic sensor for $\mathrm{Ca}^{2+}$ and $\mathrm{Pb}^{2+}$ ions. Tetrahedron Lett. 2007, 48, 7274-7278.

[12] Kao, T. L.; Wang, C. C.; Pan, Y. T.; Shiao, Y. J.; Yen, J. Y.; Shu, C. M.; Lee, G. H.; Peng, S. M.; Chung, W. S. Upper rim allyl-and arylazo-coupled calix[4]arenes as highly sensitive chromogenic sensors for $\mathrm{Hg}^{2+}$ ion. J. Org. Chem. 2005, 70, 2912-2920.

[13] Kim, T. H.; Kim, S. H.; Van, T. L.; Kim, H.; Kim, J. S. Diazo-coupled calix[4]arenes for qualitative analytical screening of metal ions. Talanta 2008, 74, 1654-1658.

[14] Liu, Z. L.; Jiang, L.; Liang, Z.; Gao, Y. H. A selective colorimetric chemosensor for lanthanide ions. Tetrahedron 2006, 62, 3214-3220.

[15] Chen, C. F.; Chen, Q. Y. Azocalix[4]arene-based chromogenic anion probes. New J. Chem. 2006, 30, 143-147.

[16] Chang, K. C.; Su, I. H.; Wang, Y. Y.; Chung, W. S. A bifunctional chromogenic calix[4]arene chemosensor for both cations and anions: a potential $\mathrm{Ca}^{2+}$ and $\mathrm{F}^{-}$switched INHIBIT logic gate with a YES logic function. Eur. J. Org. Chem. 2010, 24, 4700-4704.

[17] Chen, Y. J.; Chung, W. S. Tetrazoles and para-substituted phenylazo-coupled calix[4]arenes as highly sensitive chromogenic sensors for $\mathrm{Ca}^{2+}$. Eur. J. Org. Chem. 2009, 28, 4770-4776.

[18] Liu, L. L.; Wan, L. M.; Ren, Z. G.; Lang, J. P. Construction of a unique 3D coordination polymer from assembly of $\mathrm{Cd}\left(\mathrm{NO}_{3}\right)_{2}$ with a new tetrakis ( $m$-carboxyphenyl)azocalix[4]arene ligand. P. Inorg. Chem. Comm. 2011, 14, 1069-1072.

[19] Bayrakdar, A.; Kart, H. H.; Elcin, S.; Deligoz, H.; Karabacak, M. Synthesis and DFT calculation of a novel 5,17-di(2-antracenylazo)25,27-di (ethoxycarbonylmethoxy)-26,28-dihydroxycalix[4]arene. Spectrochim. Acta A. 2015, 136, 607-617.

[20] Rouis, A.; Mlika, R.; Dridi, C.; Davenas, J.; Ouada, B.; Halouani, H.; Bonnamour, I.; Jaffrezic, N. Optical spectroscopy studies of the complexation of chromogenic azo-calix[4]arene with $\mathrm{Eu}^{3+}, \mathrm{Ag}^{+}$and $\mathrm{Cu}^{2+}$ ions. Mater. Sci. Eng., C. 2006, 26, 247-252.

[21] Dong, Y. Y.; Kim, T. H.; Kim, H. J.; Lee, M. H.; Lee, S. Y.; Mahajan, R. K.; Kim, H.; Kim, J. S. Spectroscopic and electrochemical studies of two azocalix[4]arene derivatives. J. Elec. Chem. 2009, 628, 119-124.

[22] Serkan, E.; Gülbanu, K. C.; Alpaslan, B.; Deligöz, H. The synthesis and characterization of azocalix[4]arene based chemosensors and investigation of their properties. Spectrochim. Acta A. 2015, 142, 178-187.

[23] Tayeb, R.; Zaghbani, A.; Maamar, S. B.; Meganem, F.; Vocanson, F.; Dhahbi, M. Evaluation of an azocalix[4]arene derivative for the selective extraction of Pd (II) from hydrochloric acid solutions. C. R. Chimie 2009, 12, 1275-1279.

[24] Mlika, R.; Rouis, A.; Bonnamour, I.; Ouada, H. B. Impedance spectroscopic investigation of the effect of thin azo-calix[4] arene film type on the cation sensitivity of the gold electrodes. Mater. Sci. Eng. C. 2011, 31, 1466-1471.

[25] Shimizu, H.; Iwamoto, K.; Fujimoto, K.; Shinkai, S. Chromogenic calix[4]arene. Chem. Lett. 1991, 20, 2147-2150.

[26] Tóth, K.; Lan, B. T. T.; Jeney, J.; Horváth, M.; Bitter, I.; Grün, A.; Ágai, B.; Tódke, L. Chromogenic calix[4]arene as ionophore for potentiometric and optical sensors. Takma 1994, 41, 1041-1049.

[27] Fan, P.; Jin, Z.; Pan, Y. Synthesis and Azo-quinoid Tautomerizm of Azocalix[4]arene. Chem J. Chinese U. 2009, 30, 724-727.

[28] Benesi, H. A.; Hilderbrand, J. H. A spectrophotometric investigation of the interaction of iodine with aromatic hydrocarbons. J. Am. Chem. Soc. 1949, 71, 2703-2707. 